\title{
The environmental impact of urban transport: a case study for a new road in Catania province
}

\author{
F. Patania, A. Gagliano, F. Nocera, A. Galesi \& A. D’Amico \\ Energy and Environment Division of D.I.I.M., \\ Engineering Faculty of University of Catania, Italy
}

\begin{abstract}
The opening of a new road to car traffic could represent a symbol of socioeconomic growth for a country, but in the meantime it could also cause significant impact to the local ecosystem in the absence of a preliminary study into the environmental impact which is able to forecast if it is necessary to carry out additional works to control the immissions into the atmosphere of the polluting exhausts of motor vehicles. The estimation of impact caused by the transit of motor vehicles is quite complex because it needs to know both the state of pollution at the present time and the forecasting of further immissions of polluting gasses caused by traffic on the planned future road. To achieve this, research evaluated the effect of the construction of a provincial road "S.P. Misterbianco-Nicolosi" in order to have both an experimental validation of a dispersion code for such an outdoor environment full of anthropic obstacles as well as to evaluate the respect of the limits of polluting gaseous concentrations fixed by current Italian regulations. This paper, therefore, intends to show the results of research and the adopted rules of procedure.
\end{abstract}

Keywords: air pollutants, exhaust by vehicular traffic.

\section{Introduction}

Atmospheric pollution from exhaust gasses of road haulage is produced essentially by carbonic oxide, coming from gasoline engines, and particulate matters, coming from diesel engines.

Carbon oxide emissions during the run of a vehicle is about ten times higher in comparison with other polluting substances contained in gasoline exhaust gasses. The ultrafine dusts that can be inhaled (PM10) and the ones that can be breathed (PM 2,5 and PM 1,0) originate from diesel exhaust gasses and reach 
more than $30 \%$ of urban aerosol coming from the total urban combustions. For these reasons carbon oxide and particular matters have been chosen as chemical tracers of air pollution of road haulage.

\section{Study case}

The study case wants to discover the evaluation of air pollution induced by future road traffic of provincial road $(\mathrm{km} \mathrm{10,16),} \mathrm{which} \mathrm{is} \mathrm{actually} \mathrm{in} \mathrm{the} \mathrm{design}$ phase, that will link the north bypass of Catania city with Nicolosi town crossing Misterbianco town too, Fig.1.

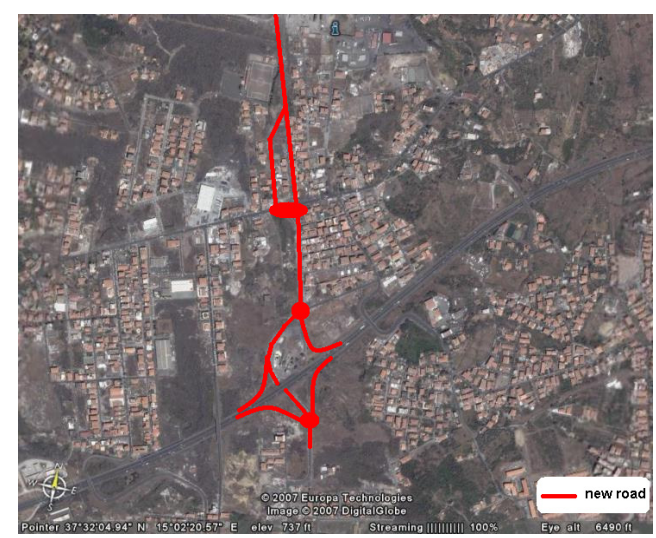

Figure 1: $\quad$ Provincial road "Misterbianco-Nicolosi".

The chemical tracers pollutants taken in consideration were CO and PM10. The research has been carried out through the following procedure:

- Analysis of every area crossed by the designed infrastructures.

- Campaign in situ of measurements both of PM10 and CO concentrations existing at the present state.

- Analysis of most significative meteoclimatic conditions presented by territory crossed by the road during the course of a year, that is a historical series of air temperature $\left({ }^{\circ} \mathrm{C}\right)$, relative humidity $(\mathrm{UR} \%)$, wind velocity $(\mathrm{m} / \mathrm{s})$ and its directions.

- Analysis of traffic flows at the present state.

- Forecast of traffic flow along designed road post operam aedificatam to forecast diffusion of air pollutants in comparison with data coming from the present state.

- Validation of the adopted model through comparison between the polluting concentration of data forecasted and those measured in situ during the campaign of measurements.

- Application of the same model but with input data related to design conditions and forecasted traffic flow of the new road. 
The previous procedure was applied in three areas of territory considered as being particularly subject to pollution, that is: Misterbianco town, Le ginestre Village, and Elio Vittorini college area.

The calculus code CALINE [1], based on Gaussian model of dispersion, so called "at plume", was used to measure the pollutant concentrations.

The values of emission factors for the pollutants considered have been extracted by the application of COPERT model [2].

Road traffic data is used to model the actual conditions which are measured in situ.

By comparing the data between the results of those from the actual location and the ones produced from the model, which relate to future conditions, it has been possible to value the "environmental compatibility" of the new road.

\section{Experimental measurements}

The whole route of the road has been subdivided into fifteen stretches so that each stretch may be considered "homogeneous" as regards traffic volume and meteoclimatic data.

Each one of the previous stretches have been allocated fifteen measure stations and further stations have been positioned near "sensible receptors" in the vicinity of the planned route of the road.

Both measurements of polluting gas and meteoclimatic conditions have been carried out as follows:

- Three days of measurements for each station: two on working days and one in a holiday period

- Four intervals of time (Observation Time) during each day of measurements, that is: $06-10 \mathrm{~h} ; 12-15 \mathrm{~h} ; 18-21 \mathrm{~h} ; 18-22 \mathrm{~h} ; 22-06 \mathrm{~h}$.

- Ten minutes of measurements for each Observation Time.

Results coming from measurements have been collected in tabular data: "cards of road traffic", Tab.1 and "report of measure", Tab.2.

\section{Measure equipments}

To measure the fractions of PM10, PM2,5 and PM 1,0 in the air, we utilized GRIMM MODEL 107. The technical characteristics of the instrument are shown in Fig. 2. To measure the concentration of toxic gasses in the air we utilized Multi Rae Plus able to measure concentrations of various gasses $\left(\mathrm{O}_{2}, \mathrm{CO}, \mathrm{CO}_{2}\right.$, $\mathrm{H} 2_{\mathrm{S}}, \mathrm{SO}_{2}, \mathrm{NO}_{\mathrm{x}}$ ) and combustible gasses too. The technical characteristics of the instrument are shown in Fig. 3.

\section{Calculus model}

The values of emissions have been calculated by the COPERT model [2].

To create a database for the COPERT model we utilized data related to yearly consumption of fuel [3], Tab. 3. 
Table 1: $\quad$ An example of a "card of road traffic".

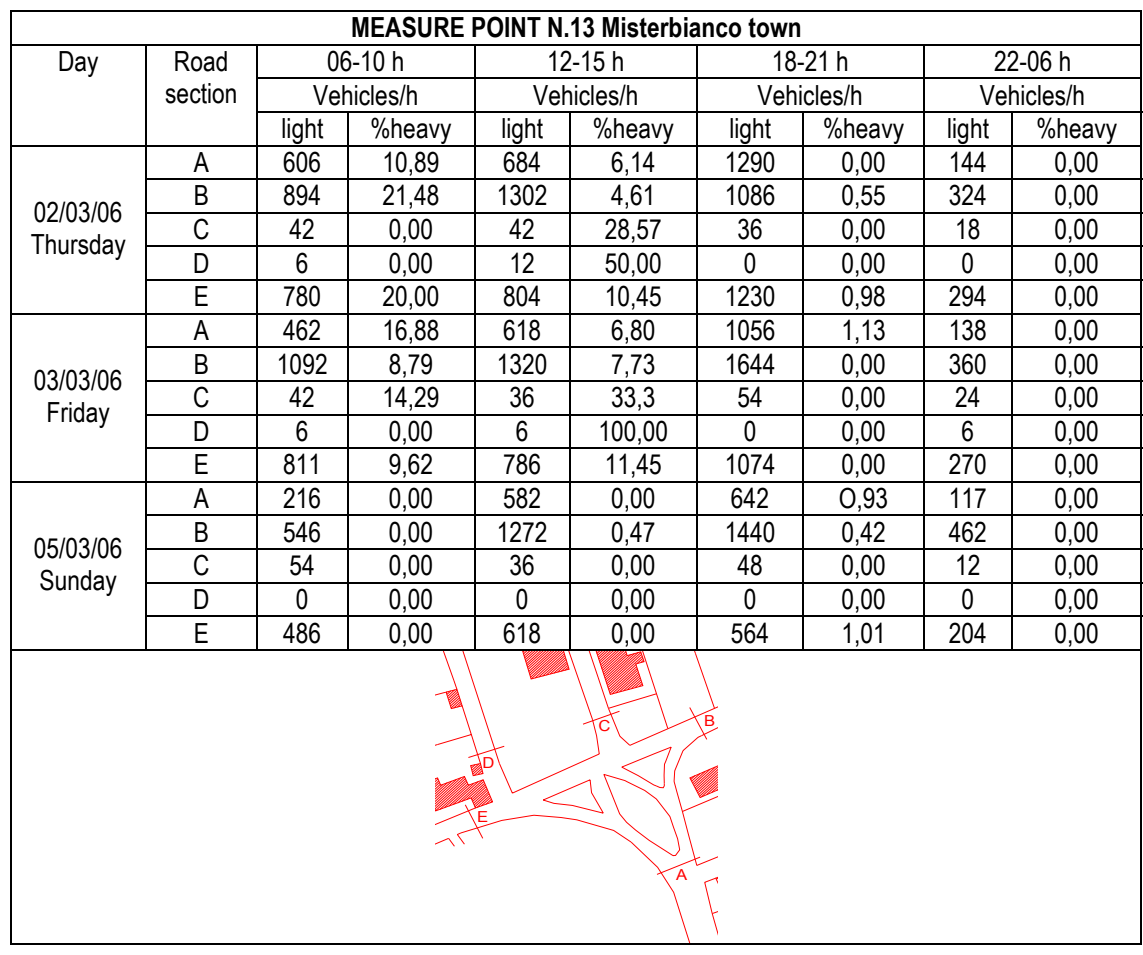

Table 2: $\quad$ Example of a "report of measure".

\begin{tabular}{|c|c|c|c|c|c|c|c|}
\hline \multicolumn{8}{|c|}{ REPORT OF MEASURE } \\
\hline \multicolumn{8}{|c|}{ MEASURE POINT N.2 Nicolosi town - Gino Cervi street } \\
\hline Day & $\mathrm{Tr}$ & To & $\begin{array}{c}\text { Temperature } \\
{ }^{\circ} \mathrm{C}\end{array}$ & $\begin{array}{c}\text { Relative } \\
\text { Umidity } \\
\%\end{array}$ & $\begin{array}{c}\text { Wind } \\
\text { velocity } \\
\mathrm{m} / \mathrm{s}\end{array}$ & $\begin{array}{l}\text { PM10 } \\
\mu \mathrm{g} / \mathrm{m}^{3}\end{array}$ & $\begin{array}{l}\mathrm{CO} \\
\mathrm{ppm}\end{array}$ \\
\hline \multirow{4}{*}{ 02-03-06 } & \multirow{4}{*}{$24 \mathrm{~h}$} & $06-10$ & 16 & 45 & 2,5 & 64,4 & 0,00 \\
\hline & & $12-15$ & 17 & 36 & 2 & 48,0 & 0,10 \\
\hline & & $18-21$ & 8,5 & 63 & 0,3 & 10,3 & 0,00 \\
\hline & & $22-06$ & 8 & 65 & 0,5 & 13,1 & 0,00 \\
\hline \multirow{4}{*}{ 03-03-06 } & \multirow{4}{*}{$24 \mathrm{~h}$} & $06-10$ & 13 & 55 & 1 & 11,5 & 0,00 \\
\hline & & $12-15$ & 14,5 & 65 & 1 & 11,5 & 0,00 \\
\hline & & $18-21$ & 6 & 90 & 1,5 & 23,6 & 0,00 \\
\hline & & $22-06$ & 6,5 & 92 & 1,5 & 25,2 & 0,00 \\
\hline \multirow{4}{*}{ 05-03-06 } & \multirow{4}{*}{$24 \mathrm{~h}$} & $06-10$ & 16 & 45 & 2,5 & 20,7 & 0,00 \\
\hline & & $12-15$ & 19 & 48 & 2,5 & 22,5 & 0,00 \\
\hline & & $18-21$ & 12,5 & 50 & 2 & 30,1 & 0,00 \\
\hline & & $22-06$ & 12,5 & 49 & 1,5 & 25,6 & 0,00 \\
\hline \multicolumn{6}{|r|}{ Min value } & 7,5 & 0,00 \\
\hline \multicolumn{6}{|c|}{ Daily mean value } & 20,8 & 0,00 \\
\hline \multicolumn{6}{|r|}{ Max value } & 71,0 & 0,10 \\
\hline
\end{tabular}


Urban Transport XIII: Urban Transport and the Environment in the 21st Century 703

\begin{tabular}{|l|l|}
\hline Mass range & $0-650 \mathrm{mg} / \mathrm{m}^{3}$ \\
\hline Accurancy & $1-20$ Mio Particle \\
\hline Flow & 1,2 liters $/ \mathrm{min}$ \\
\hline Working temperatures & $+4^{\circ} \mathrm{C}$ to $+45^{\circ} \mathrm{C}$ \\
\hline
\end{tabular}

Figure 2: $\quad$ Particles analyzer.

\begin{tabular}{|c|c|c|}
\hline Sensor & Pollutant & \\
\hline infrared & $\mathrm{CO} 2$ & \\
\hline catalitic & Combustibile gas & \\
\hline Electrochemical & $\mathrm{O} 2$ and toxic gas & \\
\hline Working temperatures & $=2208 \mathrm{C} 41458 \mathrm{C}$ & \\
\hline Working UR\% & $=0495$ & \\
\hline \multicolumn{3}{|c|}{ Sensor accuracy $=04500 \mathrm{ppm}$} \\
\hline
\end{tabular}

Figure 3: Toxic gas analyzer.

Table 3: $\quad$ Fuel consumption.

\begin{tabular}{|c|c|c|}
\hline $\begin{array}{c}\text { Yearly fuel consumption } \\
\text { (t) }\end{array}$ & Italy & Catania Province \\
\hline Gasoline & 14559 & 265,64 \\
\hline Diesel & 14682 & 267,88 \\
\hline GPL & 1106 & 20,18 \\
\hline \multicolumn{2}{|r}{} \\
\hline
\end{tabular}

- Both the maximum and minimum values of environmental temperatures related to Catania province have been deduced by "meteorological daybooks".

- The factors of emissions are calculated by the COPERT model.

- The modelling of the investigated areas has been done by CALINE 4 Caltrans implemented by the authors.

We considered each of the previous related fifteen stretches as one linear source of emission, each of them being homogeneous as regards:

- Geometrical features: typology, width of carriage way and altitude with reference to local ground. 
- Traffic features: yearly amount of running motor vehicles and their typology [4].

With reference to definition of angles of wind, we chose the azimuthal ones regarding the North direction. The ruggedness of ground surfaces around the road route has been considered unvarying in all areas crossed by a single stretch.

The meteoreologic variables of atmospheric stability (wind velocity and direction) have been considered unvarying too for each stretch.

For each homogeneous stretch, Fig. 4, we defined the right area of study by a specific calculus grid as shown in Tab. 4.

With reference to the part of the route in the area of Misterbianco town, we chose fourteen strips of road each one of them showing the same homogeneous characteristics of emissions. As regards meteoreologic data, we adopted one set of data linked to all "stability class" adopting wind velocity always less than 2,5 $\mathrm{m} / \mathrm{s}$ as discovered through the campaigns of measurements for the investigated area. In this way we fixed twelve input conditions with wind velocity varying from 1,5 to $2,5 \mathrm{~m} / \mathrm{s}$. As regards wind direction, measurements in situ show an excessive variability and for this reason we have been obliged to consider twenty four possible directions $\left(0^{\circ}, 15^{\circ}, 30^{\circ} \ldots 360^{\circ}\right)$. After all, we considered 288 possible meteo conditions as shown in Tab. 5 .

Table 4: $\quad$ Calculus grid.

\begin{tabular}{|l|l|}
\hline \multicolumn{2}{|c|}{ GRID } \\
\hline Origin : $x$-axis $; y$-axis & $677,51 \mathrm{~m} ; 288,11 \mathrm{~m}$ \\
\hline $\mathrm{N}$ point $\mathrm{x}$-axis $; \mathrm{y}$-axis & $100 ; 100$ \\
\hline Dx dy & $3,16 \mathrm{~m} ; 10.48 \mathrm{~m}$ \\
\hline Mean Altitude & $230 \mathrm{~m}$ \\
\hline Ground elevation & $1.5 \mathrm{~m}$ \\
\hline Roughness & $10 \mathrm{~cm}$ \\
\hline
\end{tabular}

Table 5: $\quad$ Meteo conditions.

\begin{tabular}{|c|c|c|c|c|c|c|c|c|}
\hline \multirow{2}{*}{$\begin{array}{c}\text { Wind } \\
\text { Direction } \\
0\end{array}$} & \multirow{2}{*}{$\begin{array}{c}\text { Wind } \\
\text { Velocity } \\
\text { to North }\end{array}$} & \multicolumn{6}{|c|}{ Class of stability } \\
\cline { 3 - 8 } & $\mathbf{m} / \mathbf{s}$ & $A$ & $B$ & $C$ & $D$ & $E$ & $F+G$ \\
\cline { 3 - 8 } & & \multicolumn{6}{|c|}{ Meteo conditions } \\
\hline 15 & 1,5 & 1 & 2 & 3 & 4 & 5 & 6 \\
\hline 15 & 2,5 & 7 & 8 & 9 & 10 & 11 & 12 \\
\hline$\ldots$ & $\ldots$ & $\ldots$ & $\ldots$ & $\ldots$ & $\ldots$ & $\ldots$ & $\ldots$ \\
\hline 360 & 1,5 & 277 & 278 & 279 & 280 & 281 & 282 \\
\hline 360 & 2,5 & 283 & 284 & 285 & 286 & 287 & $\mathbf{2 8 8}$ \\
\hline
\end{tabular}




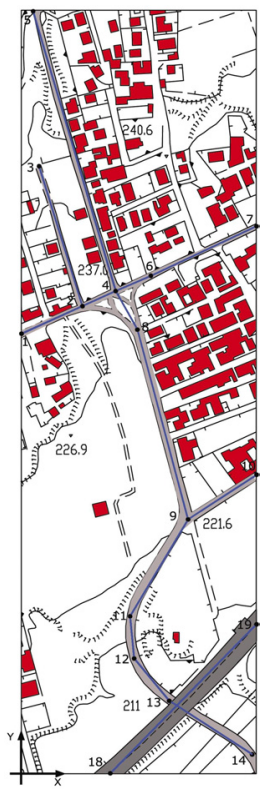

Figure 4: Misterbianco town: homogeneous stretch of road.

\section{Results of simulations at actual state}

Tab. 6 and Fig. 5 show the results respectively of concentrations of PM10 and $\mathrm{CO}$ in each receptor, the map of isoconcentration of PM10 and that of isoconcentrations of $\mathrm{CO}$ in one strip of the investigated area of Misterbianco town.

The validation of model has been done through comparison between data coming from campaigns of measurements, as previously related, and those by application of the Caline model: both data related to the same time of observation. One can observe the difference between the measured data and those forecasted in Tab. 7.

Such a procedure of comparison allows one to determine the range of diverging, that is the divergence of the values, between the two series of data (measured and forecasted) so to discover if such a difference can cause the exceeding of limits of concentrations fixed by rules in each single receptor and, consequently, to design the appropriate work of acoustical control when the limits are overcome.

Table 6: CO-PM10 concentration.

\begin{tabular}{|c|c|c|c|c|}
\hline Reptors & $\begin{array}{c}\mathbf{X} \\
(\mathbf{m})\end{array}$ & $\begin{array}{c} \\
(\mathrm{m})\end{array}$ & $\begin{array}{c}\text { PM10 } \\
\left(\mu \mathrm{g} / \mathbf{m}^{3}\right)\end{array}$ & $\begin{array}{c}\mathrm{CO} \\
(\mathrm{ppm})\end{array}$ \\
\hline 1 & 677.51 & 891.41 & 20,5 & $\mathrm{O}, 12$ \\
\hline 2 & 759.45 & 929.16 & 21,0 & 0,15 \\
\hline & & & & \\
\hline 13 & 988.91 & 317.66 & 20,8 & 0,18 \\
\hline
\end{tabular}




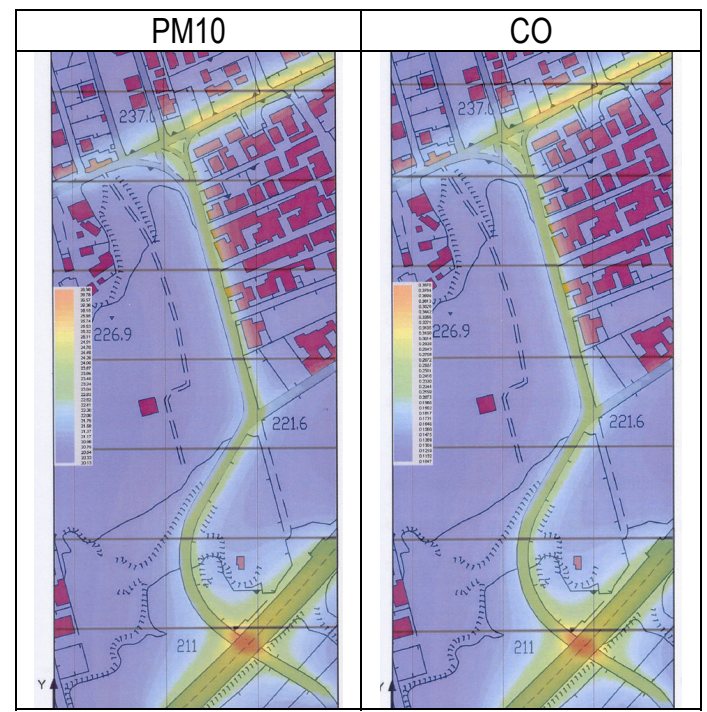

Figure 5: $\quad$ PM10 and $\mathrm{CO}$ isoconcentration maps.

Table 7: Validation of results.

\begin{tabular}{|c|c|c|c|c|c|}
\hline \multirow[t]{2}{*}{$\begin{array}{c}\text { Investigated } \\
\text { Area }\end{array}$} & \multirow[t]{2}{*}{$\begin{array}{c}\text { Measure } \\
\text { point }\end{array}$} & $\begin{array}{lr}\text { (1)PM10 limit } & \text { limilue } \\
\text { valialian } \\
\text { regulation) }\end{array}$ & $\begin{array}{c}\text { (2) } \mathrm{PM}_{10} \text { mean } \\
\text { measured } \\
\text { value }\end{array}$ & $\begin{array}{c}\text { (3) } \mathrm{PM}_{10} \\
\text { forecasted } \\
\text { value }\end{array}$ & $\Delta=(1)-(3)$ \\
\hline & & \multicolumn{4}{|c|}{$\mu \mathrm{g} / \mathrm{m}^{3}$} \\
\hline \multirow{4}{*}{ Misterbianco } & 12 & \multirow{5}{*}{50} & 20,2 & 21,2 & 28,8 \\
\hline & 13 & & 23,9 & 26,7 & 23,3 \\
\hline & 14 & & 23,2 & 27,0 & 23,0 \\
\hline & 15 & & 21,8 & 23,4 & 26,6 \\
\hline E. Vittorinil & 9 & & 21,7 & 26,60 & 23,4 \\
\hline \multirow[t]{2}{*}{ Simulated Area } & \multirow{2}{*}{$\begin{array}{c}\text { Measure } \\
\text { point }\end{array}$} & $\begin{array}{l}\text { (1)CO limit value } \\
\text { (Italian regulation) }\end{array}$ & $\begin{array}{l}\text { (2) CO mean } \\
\text { measured } \\
\text { value }\end{array}$ & $\begin{array}{c}\text { (3) CO } \\
\text { forecasted } \\
\text { value }\end{array}$ & $\Delta=(1)-(3)$ \\
\hline & & \multicolumn{4}{|c|}{$\mathrm{mg} / \mathrm{m}^{3}$} \\
\hline \multirow{4}{*}{ Misterbianco } & 12 & \multirow{5}{*}{15} & 0,11 & 0,55 & 14,45 \\
\hline & 13 & & 0,26 & 0,42 & 14,58 \\
\hline & 14 & & 0,24 & 0,50 & 14,50 \\
\hline & 15 & & 0,18 & 0,37 & 14,63 \\
\hline E. Vittorini & 9 & & 0,013 & 0,13 & 14,87 \\
\hline
\end{tabular}

\section{Results of simulation at the forecast state (post operam aedificatam)}

The modelling of the forecasted state has been carried out by the same criteria previously referred, utilizing the same meteoclimatic and morphological characteristics and the same investigated areas. The only changing concerns were: very little diverging of road axis in same zones in comparison with the position of axis of the actual road, a little additional strip of road and some road steep slopes. 
All these possibilities do not influence significatively the procedures previously adopted. Also the new road (Fig.6) has been schematized through fifteen links each one being homogeneous as regards polluting emissions.

Tab. 8 and Tab. 9 show the results respectively of concentrations of PM10 and $\mathrm{CO}$ in each receptor whilst figure 7 shows the maps of isoconcentrations both of PM10 and CO in the strip shown in Fig. 6.

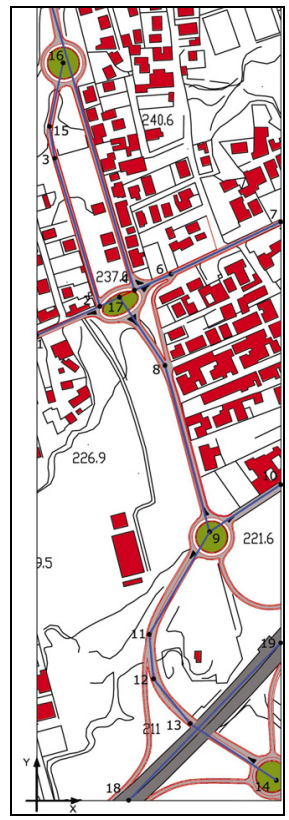

Figure 6: The future route of road.

Table 8: $\quad$ PM10 concentrations.

\begin{tabular}{|c|c|c|c|c|}
\hline $\begin{array}{c}\text { Investigated } \\
\text { Area }\end{array}$ & Measure point & $\begin{array}{c}\text { Measured } \\
\text { value } \\
\mu \mathrm{g} / \mathrm{m}^{3}\end{array}$ & $\begin{array}{c}\text { Forecasted } \\
\text { value } \\
\mu \mathrm{g} / \mathrm{m}^{3}\end{array}$ & $\begin{array}{c}\Delta \\
\end{array}$ \\
\hline \multirow{4}{*}{ 1- Misterbianco } & & 20.1 & 24.2 & 4.1 \\
& (12) Misterbianco - Campo sportivo & 20.8 & 23.4 & 2.6 \\
& (13) Misterbianco - S.P.N12/l & 21.4 & 25.0 & 3.6 \\
& (14) Misterbianco - via Amenano & 21.4 & 26.2 & 3.8 \\
\hline
\end{tabular}

Table 9: $\quad$ CO concentrations.

\begin{tabular}{|c|c|c|c|c|}
\hline $\begin{array}{c}\text { Investigated } \\
\text { Area }\end{array}$ & Measure point & $\begin{array}{c}\text { Measured } \\
\text { value } \\
\mathrm{ppm}\end{array}$ & $\begin{array}{c}\text { Forecasted } \\
\text { value } \\
\mathrm{ppm}\end{array}$ & $\begin{array}{c}\Delta \\
\mathrm{ppm}\end{array}$ \\
\hline \multirow{5}{*}{ - Misterbianco } & 12) Misterbianco - Campo sportivo & 0.00 & 0 & 0 \\
& (13) Misterbianco - S.P.N12/I & 0.00 & 0.11 & 0.11 \\
& (14) Misterbianco - via Amenano & 0.11 & 0.23 & 0.12 \\
& (15) Misterbianco - Lineri & 0.10 & 0.20 & 0.10 \\
\hline
\end{tabular}


708 Urban Transport XIII: Urban Transport and the Environment in the 21st Century

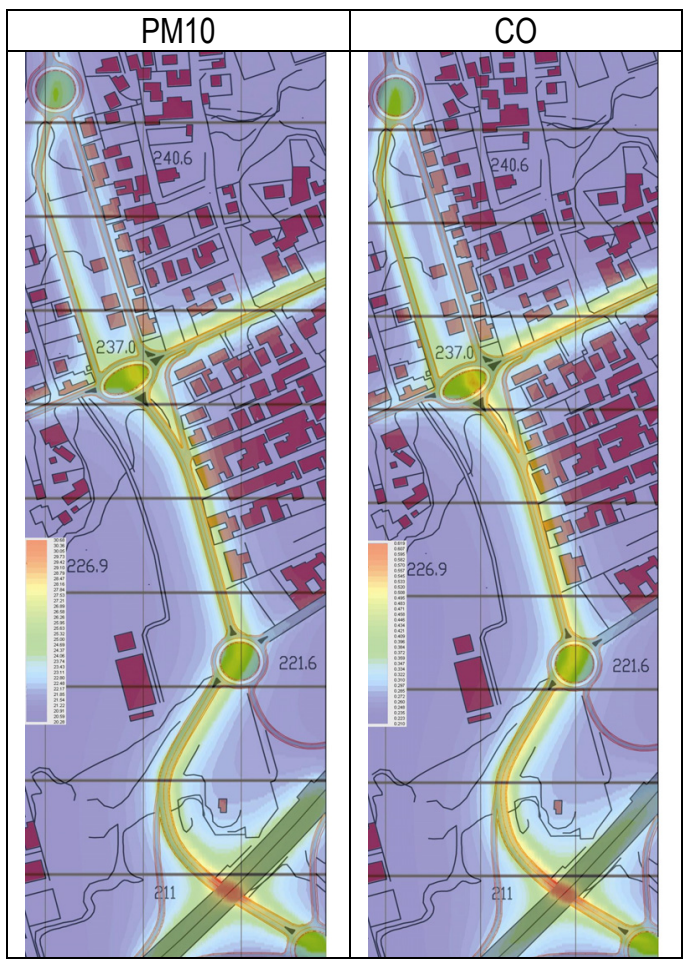

Figure 7: $\quad$ PM10 and CO isoconcentration maps.

Table 10: $\quad$ PM10 forecasted values.

\begin{tabular}{|c|c|c|c|c|c|}
\hline \multirow{2}{*}{$\begin{array}{c}\text { Investigated } \\
\text { Area }\end{array}$} & $\begin{array}{c}\text { Measure } \\
\text { point } \\
\mathrm{N} .\end{array}$ & $\begin{array}{l}\text { (1) PM10 limit } \\
\text { value (Italian } \\
\text { regulation) }\end{array}$ & $\begin{array}{l}\text { (2) PM10 mean } \\
\text { forecasted value }\end{array}$ & \begin{tabular}{c} 
(3) $\begin{array}{c}\text { PM } \\
\text { maximum } \\
\text { forecasted value }\end{array}$ \\
\cline { 4 - 6 }
\end{tabular} & \multicolumn{4}{|c|}{$\mu \mathrm{g} / \mathrm{m}^{3}$} \\
\hline Misterbianco & 9 & \multirow{2}{*}{50} & 27,0 & 44,2 & 5,8 \\
\hline E. Vittorini & 11 & \multirow{2}{*}{50} & 26,4 & 41,6 & 8,4 \\
\hline Le Ginestre & 2 & & 26,5 & 44,1 & 5,9 \\
\cline { 4 - 6 }
\end{tabular}

Table 11: $\quad$ CO forecasted values.

\begin{tabular}{|c|c|l|c|c|c|}
\hline \multirow{2}{*}{$\begin{array}{c}\text { Investigated } \\
\text { Area }\end{array}$} & $\begin{array}{c}\text { Measure } \\
\text { point } \\
\mathrm{N} .\end{array}$ & $\begin{array}{l}\text { (1) CO limit value } \\
\text { (Italian } \\
\text { regulation) }\end{array}$ & $\begin{array}{c}\text { (2) CO mean } \\
\text { forecasted } \\
\text { value }\end{array}$ & $\begin{array}{c}\text { (3) COmaximum } \\
\text { forecasted value }\end{array}$ & $\Delta=(1)-(3)$ \\
\hline Misterbianco & 9 & \multirow{3}{|c|}{$\mathrm{mg} / \mathrm{m}^{3}$} \\
\hline \multirow{2}{*}{ E. Vittorini } & 11 & \multirow{2}{*}{15} & 0,50 & 1,17 & 14,45 \\
\hline Le Ginestre & 2 & & 0,16 & 0,45 & 14,55 \\
\cline { 4 - 6 } & & 0,27 & 0,99 & 14,01 \\
\hline
\end{tabular}




\section{Remarks on results and conclusions}

Tab. 10 and Tab. 11 show in which receptors concentrations of PM10 and CO reach the biggest forecasted values, and the average and also the permitted values too.

It is can be seen that as regard PM10 pollution, the annual limits of concentration allowed by Italian rules is very unlikely to be exceeded and even random levels will be lower than permitted by Italian regulation (n.35/year).

For annual CO pollution in more impacted receptors, forecasted concentrations are amply lower than that allowed by the current rules and there is a large margin of safety for inhabitants. In conclusion, the construction of the new road does not present problems of pollution of the atmosphere or any danger to the health of the inhabitants of the area, so it is possible to confirm the environmental compatibility of the newly designed road.

In another paper the Authors will show the environmental incompatibility of the road as regards its acoustical impacts on resident people.

\section{References}

[1] California Department of Transportation (CALTRANS). CALINE4, Dispersion Model for Predicting Air pollutant Concentrations Near Roadways.

[2] European Environment Agency. COPERT- Computer Program to calculate Emissions of Road Transport.

[3] Ministry of Productive Activity - General Direction of Energy and Mineral Resources -Statistical Observatory of Energy

[4] National Agency for Environment Preservation (ANPA), Italy Interdepartmental Census of the Emission's Sources.

[5] F. Patania, A. Gagliano, F. Nocera, A. Galesi, A. D'Amico - An applied research to forecast the trend of air pollution coming from multifloors parkings-Urban Transport 2006 - Prague, Czech Republic, 12-14 July 2006

[6] F. Patania, A. Gagliano, F. Nocera, A. Galesi, A. D'Amico - An applied research to forecast the trend of air pollution in particular geometries of streets: the real case of urban canyon-Air Pollution XIV, The New Forest, UK, 22-24 May 2006 